\title{
HUBUNGAN KUALITAS PELAYANAN KESEHATAN DENGAN TINGKAT KEPUASAN PASIEN TB PARU YANG MENJALANI PROGRAM PENGOBATAN
}

\author{
Henny Syapitri ${ }^{1}$, Johansen Hutajulu ${ }^{2}$, Novita Aryani ${ }^{3}$, Frida Liharis Saragih ${ }^{4}$ \\ 1,2,3,4 Universitas Sari Mutiara Indonesia \\ Email : heny_syahfitri86@yahoo.com
}

\begin{abstract}
ABSTRAK
Tuberkulosis masih menjadi masalah kesehatan baik di Indonesia maupun di dunia dan merupakan penyebab kematian utama. Strategi DOTS merupakan program pengendalian tuberkulosis. Program ini dilaksanakan oleh Puskesmas Helvetia dan diharapkan jumlah penderita tuberkulosis menurun. Kualitas pelayanan merupakan suatu bentuk kegiatan yang dilakukan oleh pelayanan kesehatan berupa pelayanan, proses, dan lingkungan yang memenuhi atau melebihi harapan. Kepuasan suatu pertimbangan diberikan saat pasien mendapat perawatan. Penelitian ini bertujuan untuk mengetahui hubungan kualitas kesehatan dengan strategi pengobatan DOTS Tuberkulosis. Jenis penelitian yang digunakan dalam penelitian ini adalah analitik korelasi dengan metode cross sectional, sampel dalam penelitian ini adalah pasien yang menjalani strategi pengobatan Tuberculosis DOTS. Sampel penelitian sebanyak 48 responden yang dipilih secara consecutive sampling. Data analisis hubungan kualitas pelayanan kesehatan dengan tingkat kepuasan diperoleh nilai signifikan $p=0,003$ dan nilai $r=0,423$. Kemudian terdapat hubungan antara kualitas pelayanan kesehatan dengan tingkat kepuasan. Disarankan untuk lebih meningkatkan pelayanan keperawatan guna meningkatkan kenyamanan dan kesehatan pasien.
\end{abstract}

Kata kunci : TB Paru, Kualitas Pelayanan, Kepuasan. 


\title{
HEALTH SERVICE QUALITY RELATIONSHIP WITH THE LEVEL OF PATIENTS SATISFACTION WITH LUNG TB THAT FOLLOWS TREATMENT PROGRAM
}

\begin{abstract}
Tuberculosis is still a health problem both in Indonesian and in the world and is the leading cause of death. DOTS strategy is the tuberculosis control program. This program carried out by the health center Helvetia and the expeted number of patients with tuberculosis decreased. Quality of service is a form of activity undertaken by health services such a service, processes, and environment that meet or exceed expectations. The Satisfaction of a judgment given when the patients gets care. This study aims to determine the relationship of quality health Tuberculosis DOTS treatment strategy. The type of research used in this study is an analytic correlation using cross sectional method, samples in this study were patients who underwent Tuberculosis DOTS treatment strategy. The samples of the study was 48 respondents choose by consecutive sampling. Data were analysis of health care quality relationship with the level of satisfaction obtained significant value $p=0,003$ and the value of $r=0,423$. Then there is a relationship between the quality of health services with the level of satisfaction. It is advisable to further improve nursing services in order to increase the comfort and the health of patient.
\end{abstract}

Keywords : Pulmonary TB, Quality health care, Satisfaction.

\section{PENDAHULUAN}

Penyakit TB Paru masih menjadi masalah kesehatan dunia terutama negara yang berkembang. Besarnya masalah tersebut terlihat dari tingginya angka kesakitan dan kematian akibat TB Paru (Riskesdas, 2013). Diperkirakan 1/3 dari penduduk dunia tanpa diketahui terinfeksi Mycobacterium Tuberkulosis dan sekitar 95\% penderita TB Paru berada di negara berkembang, dimana $75 \%$ diantaranya adalah usia produktif. TB Paru biasanya mengenai usia dewasa muda antara 15-44 tahun. World Health Organization (WHO) melaporkan bahwa terdapat 22 negara dengan jumlah kasus TB Paru terbanyak di dunia dan ke 22 negara ini disebut sebagai "high burden countries". Tiga Negara yang termasuk dalam high burden countries berada di Asia Tenggara, yaitu: Cina, India dan Indonesia. WHO menyebutkan bahwa jumlah terbesar kematian akibat TB terdapat di Asia Tenggara yaitu 625.000 orang.

Di Indonesia setiap tahun terjadi 540 kasus baru dengan kematian 120 penderita Tuberkulosis positif pada dahaknya. 
Prevalensi TB BTA positif di Indonesia dikelompokkan menjadi 3 wilayah, yaitu: wilayah Sumatera dengan angka prevalensi TB 160 per 100.000 penduduk, wilayah Jawa dan Bali dengan angka prevalensi 110 per 100.000 penduduk, wilayah Indonesia Timur dengan angka prevalensi 68 per 100.000 penduduk (Depkes, 2011).

Tujuan dari program penanggulangan tuberkulosis nasional, yaitu angka penemuan kasus miniman $70 \%$ dan angka kesembuhan minimal $85 \%$, dimana penatalaksanaan penyakit TB merupakan hal penting yang harus diperhatikan yaitu tidak sekedar memastikan pasien menelan obat sampai dinyatakan sembuh, tetapi juga berkaitan dengan pengelolaan sarana bantu yang dibutuhkan, petugas yang terkait, pencatatan, pelaporan, evaluasi kegiatan dan rencana tindak lanjutnya. Sehingga dalam jangka waktu 5 tahun kedepan angka prevalensi TB di Indonesia dapat diturunkan sebesar 50\% (Depkes, 2011).

Salah satu strategi untuk mencapai misi Indonesia sehat adalah dengan meningkatkan akses masyarakat terhadap pelayanan kesehatan yang berkualitas dengan sasaran utamanya adalah tersedianya sumber daya manusia yang kompeten di setiap desa, pelayanan kesehatan di rumah sakit, puskesmas dan jaringan memenuhi mutu. Meningkatnya kesadaran masyarakat terhadap pelayanan kesehatan, akan mengakibatkan tuntutan peningkatan pelayanan kesehatan. Salah satu upaya mengantisipasi keadaan tersebut dengan menjaga kualitas pelayanan, sehingga perlu dilakukan upaya terus menerus agar dapat diketahui kelemahan dan kekurangan jasa pelayanan kesehatan (Jarusliaman, 2015).

Semakin meningkatnya tuntutan masyarakat akan kualitas pelayanan kesehatan, maka fungsi pelayanan perlu ditingkatkan untuk memberi kepuasan pasien. Kualitas pelayanan merupakan suatu bentuk penilaian konsumen (pasien) terhadap tingkat pelayanan kesehatan yang diberikan menunjuk pada tingkat kesempurnaan pelayanan kesehatan dalam memenuhi kebutuhan dan tuntutan setiap pasien, makin sempurna kebutuhan dan tuntutan setiap pasien, makin baik pula mutu pelayanan kesehatan (Ira, 2013).

Layanan kesehatan yang bermutu sering dipersepsikan sebagai suatu layanan kesehatan yang dibutuhkan, dalam hal ini akan ditentukan oleh profesi layanan kesehatan dan sekaligus diinginkan baik oleh klien (individu) ataupun masyarakat serta terjangkau oleh daya beli masyarakat, serta dapat memuaskan setiap pemakai jasa pelayanan kesehatan sesuai tingkat kepuasan rata-rata penduduk. Penyelenggaraannya juga harus sesuai dengan standard dan kode etik profesi yang telah ditetapkan. Pasien cenderung memilih atau menetapkan prioritas indikator kualitas pelayanan kesehatan, sebagai dasar untuk memutuskan tingkat kepuasannya (Erviana, 2013).

Untuk tercapainya tujuan tersebut puskesmas sebagai pelaksana program penanggulangan TB Paru di masyarakat perlu melakukan evaluasi terhadap kegiatan yang dilakukan dalam memberikan pelayanan kepada penderita TB Paru dengan cara mengukur atau menilai kepuasan penderita TB (Jarusliaman, 2015). 
Kepuasan pasien merupakan respon evaluatif, afektif atau emosional yang terkait dengan mutu pelayanan yang diberikan rumah sakit serta harapan pasien terhadap pelayanan tersebut. Metode terpopuler untuk menilai mutu pelayanan adalah melihat mutu pelayanan dari 6 dimensi yaitu pemahaman tentang pelayanan yag diberikan, empati, penampilan fisik, jaminan keamanan, keandalan dan kecepatan (Like, 2011).

Berdasarkan data survey awal di Puskesmas Medan Helvetia diperoleh data jumlah penderita TB Paru 108 orang dengan TB BTA (+) baru diobati. Data ini menggambarkan bahwa masih terdapat penderita TB Paru diwilayah kerja puskesmas Helvetia Medan setiap bulannya, walaupun telah dilakukan program penanggulangan TB Paru dengan strategi DOTS. Untuk melihat pelaksanaan program tersebut maka perlu dilakukan pengukuran yang dinilai dari sudut pandang penderita TB Paru tentang kepuasannya dalam menjalani program pengobatan TB Paru.

Berdasarkan latar belakang tersebut, perlu dilakukan penelitian terkait Hubungan pelayanan kesehatan dengan kepuaan pasien TB Paru yang menjalani program pengobatan.

\section{METODE PENELITIAN}

Jenis penelitian yang digunakan pada penelitian ini adalah penelitian analitik korelasi dengan menggunakan metode pendekatan cross sectional.

Populasi dalam penelitian ini adalah pasien Tuberculosis Paru yang menjalani pengobatan di Puskesmas Helvetia Medan sebanyak 76 orang. Sampel dalam penelitian ini sejumlah 48 orang dengan menggunakan tehnik purposive sampling dengan kriteria sampel: yaitu pasien TB Paru yang sedang menjalani pengobatan fase awal.

Instrument yang digunakan dalam penelitian adalah Kuisioner. Hasil Validitas dan reliabilitas diuji dengan korelasi Pearson Product Moment dan Cronbach's alpha, dengan nilai Cronbach Alpha lebih besar dari 0,744. Artinya, instrumen tersebut dalam kategori sangat tinggi dan dinyatakan reliabel untuk digunakan dalam penelitian. Analisis data yang digunakan adalah analisis bivariat, dengan menggunakan uji spearman dengan tingkat kepercayaan (Confident Interval) 95\% dan batas kemaknaan alfa $5 \%$. 


\section{HASIL}

\section{a. Distribusi Frekuensi Kualitas Pelayanan Kesehatan di Puskesmas Helvetia}

\section{Tabel 1}

\section{Distribusi Frekuensi Kualitas Pelayanan}

\begin{tabular}{lcc}
\hline \multicolumn{1}{c}{ Kualitas } & Frekuensi (f) & Persentasi (\%) \\
Pelayanan & & \\
\hline Cukup & 6 & 12,5 \\
Baik & 42 & 87,5 \\
\hline Total & $\mathbf{4 8}$ & $\mathbf{1 0 0}$ \\
\hline
\end{tabular}

Tabel 1 menunjukkan kualitas pelayanan di Puskesmas Helvetia Medan menurut pasien TB Paru yang menjalani pengobatan strategi DOTS mayoritas kategori baik yaitu sebanyak 42 orang $(87,5 \%)$.

b. Distribusi Kepuasan Pasien TB Paru di Puskesmas Helvetia

Tabel 2

Distribusi Frekuensi Kepuasan Pasien

\begin{tabular}{lcc}
\hline \multicolumn{1}{c}{ Kepuasan } & Frekuensi (f) & Persentasi (\%) \\
\hline Tidak puas & 3 & 6,3 \\
Puas & 45 & 93,7 \\
\hline Total & $\mathbf{4 8}$ & $\mathbf{1 0 0}$ \\
\hline
\end{tabular}

Tabel 2 menunjukkan tingkat kepuasan pasien TB Paru yang menjalani pengobatan strategi DOTS mayoritas puas yaitu sebanyak 45 orang $(93,8 \%)$.

c. Hubungan Kualitas Pelayanan Kesehatan dengan Kepuasan Pasien

Tabel 3

Hubungan Kualitas Pelayanan Kesehatan dengan Kepuasan

\begin{tabular}{|c|c|c|c|c|c|c|c|c|}
\hline \multicolumn{9}{|c|}{ Kepuasan Pasien } \\
\hline \multirow{2}{*}{$\begin{array}{l}\text { Kualitas } \\
\text { Pelayanan }\end{array}$} & \multicolumn{2}{|c|}{ Tidak Puas } & \multicolumn{2}{|c|}{ Puas } & \multicolumn{2}{|c|}{ Total } & \multirow[t]{2}{*}{$P$ Value } & $\mathbf{r}$ \\
\hline & $\mathbf{n}$ & $\%$ & $\mathbf{n}$ & $\%$ & $\mathbf{n}$ & $\%$ & & \\
\hline
\end{tabular}




\begin{tabular}{lcccccccc}
\hline Cukup & 2 & $4,2 \%$ & 4 & $8,3 \%$ & 6 & $12,5 \%$ & 0,003 & 0,423 \\
Baik & 1 & $2,1 \%$ & 41 & $85,4 \%$ & 42 & $87,5 \%$ & & \\
& & & & & & & \\
\cline { 1 - 6 } Total & $\mathbf{3}$ & $\mathbf{6 , 3 \%}$ & $\mathbf{4 5}$ & $\mathbf{9 3 , 7 \%}$ & $\mathbf{4 8}$ & $\mathbf{1 0 0 \%}$ & & \\
\hline
\end{tabular}

Tabel 3 menunjukkan bahwa terdapat hubungan yang signifikan antara kualitas pelayanan kesehatan dengan tingkat kepuasan pada pasien TB Paru yang menjalani pengobatan strategi DOTS di Puskesmas Helvetia Medan, diperoleh $\mathrm{p}$ value $0,003<\alpha 0,05$. Hasil uji korelasi diperoleh nilai $r=0,423$ artinya kekuatan

\section{PEMBAHASAN}

\section{Kualitas Pelayanan}

Hasil penelitian yang diperoleh dari 48 responden diketahui bahwa kualitas pelayanan di Puskesmas Helvetia Medan mayoritas baik yaitu 87,5\%. Menurut Nurcaya (2011) kualitas pelayanan merupakan evaluasi kognitif jangka panjang pasien terhadap penyerahan jasa suatu Puskesmas. Pada umumnya pelayanan yang diberikan Rumah Sakit baik akan menghasilkan kepuasan yang tinggi juga. Kualitas Pelayanan dikatakan baik jika memenuhi 5 dimensi antara lain: ketampanan fisik (tangibles), daya tanggap (responsiveness), kehandalan (reliability), jaminan (assurance) dan empati (empathy).

Pemberian kualitas pelayanan membutuhkan interaksi yang baik antara petugas atau pemberi pelayanan dengan pasien. Apabila pemberi layanan memberikan pelayanan dengan cara dan hasil yang baik, maka itu akan menimbulkan kesan yang baik pula (Setyaningsih, 2011). Kualitas pelayanan di hubungan antara kualitas pelayanan kesehatan dengan tingkat kepuasan memiliki korelasi sedang. Hal ini menyimpulkan bahwa semakin baik kualitas pelayanan yang diberikan pelayan kesehatan maka semakin puas pula kepuasan pasien yang menjalani pengobatan.

Puskesmas tergantung dari waktu pelayanan (makin singkat makin disenangi pasien) dan penanganan yang efektif. Pasien memilih pelayanan dengan mempertimbangkan kenyamanan pelayanan, kualitas keterampilan pelayanan (Rizal, 2014).

Pelayanan yang berkualitas dapat dikatakan apabila telah memberikan kepuasan untuk pasien. Semakin baik kualitas pelayanan maka semakin puas perasaan yang akan ditimbulkan oleh pasien terhadap pelayanan kesehatan yang diterima oleh pasien tersebut dan tingkat kepuasan pasien erat kaitannya dengan kualitas pelayanan yang diberikan (Bata, 2013).

Pelayanan kesehatan yang berkualitas adalah pelayanan kesehatan yang dapat memuaskan setiap pemakai jasa pelayanan kesehatan sesuai tingkat kepuasan rata-rata penduduk. Penyelenggaraannya juga harus sesuai dengan standard an kode etik profesi yang telah ditetapkan. Pasien cenderung memilih atau menetapkan prioritas indikator kualitas pelayanan kesehatan, sebagai dasar untuk memutuskan tingkat kepuasannya (Maidelwita, 2011). 


\section{Kepuasan}

Hasil penelitian yang diperoleh dari 48 responden diketahui bahwa mayoritas kepuasaan atas pelayanan di Puskesmas Helvetia Medan adalah puas yaitu 93,7\%. Menurut setyaningsih (2011) kepuasan pasien dapat mencerminkan baik intervensi yang diterima pasien.

Hasil beberapa survei menunjukkan bahwa kepuasan pasien banyak dipengaruhi secara langsung oleh kualitas pelayanan yang diberikan pelayan kesehatan terutama yang berhubungan dengan fasilitas, proses pelayanan dan sumber daya yang bekerja. Berdasarkan hasil analisis kuisoner sebaagian besar keluhan pasien dalam suatu survei kepuasan menyangkut tentang keberadaan petugas yang tidak professional dalam memberikan pelayanan kesehatan diantaranya masih terdengar keluhan akan petugas yang tidak ramah dan acuh terhadap keluhan pasiennya. Selain itu juga masih sering terdengar tentang sulitnya meminta informasi dari tenaga kesehatan terutama dokter dan perawat, sulitnya untuk berkomunikasi dua arah dengan tenaga kesehatan dan lain sebagainya yang mencerminkan betapa lemahnya posisi pasien sebagai penerima jasa layanan kesehatan.

Kepuasan pelanggan terhadap kualitas pelayanan dapat ditentukan dengan membandingkan persepsi dari pelayanan yang diterima dengan harapan terhadap pelayanan kesehatan yang diberikan. Jika harapan itu terlampaui, pelayanan tersebut dirasakan sebagai kualitas yang luar biasa dan juga menadi kejutan yang menyenangkan. Jika harapan tidak terlampaui, kualitas pelayanan tersebut dianggap tidak dapat diterima atau mengecewakan konsumen dan jika harapan sama dengan pelayanan yang dirasakan, kualitas memuaskan (Rizal, 2014).

Pasien yang mengalami kepuasan terhadap layanan kesehatan yang diiselenggarakan cenderung mematuhi nasihat, setia, atau taat terhadap rencana pengobatan yang telah disepakati. Sebaliknya pasien yang tidak merasakan kepuasan atau kekecewaan sewaktu menggunakan layanan kesehatan cenderung tidak mematuhi rencana pengobatan, tidak mematuhi nasihat, berganti dokter atau pindah ke fasilitas layanan kesehatan lainnya (Chitami, 2013).

\section{Hubungan Kualitas Pelayanan Kesehatan dengan Tingkat Kepuasan}

Hasil uji statistik spearman, diperoleh nilai signifikasi sebesar $0,003<\alpha 0,05$. Artinya ada hubungan yang signifikan antara kualitas pelayanan kesehatan dengan tingkat kepuasan pasien TB Paru yang menjalani pengobatan strategi DOTS di Puskesmas Helvetia Medan.

Kualitas pelayanan kesehatan yang dimiliki sebuah pelayan kesehatan mempengaruhi pasien dalam menggunakan sebuah jasa pelayanan kesehatan. Kualitas adalah suatu kondisi dinamis yang berhubungan dengan produk jasa, manusia, proses dan lingkungan yang memenuhi atau melebihi harapan, bukan hanya menekankan pada aspek hasil akhir (Zaniarti, 2011).

Kepuasan terhadap kualitas pelayanan dapat ditentukan dengan membandingkan 
persepsi dari pelayanan yang diterima dengan harapan terhadap pelayanan yang diberikan. Jika harapan itu terlampaui, pelayanan tersebut dirasakan sebagai kualitas yang luar biasa dan juga menjadi kejutan yang menyenangkan. Jika harapan tidak terlampaui, kualitas pelayanan tersebut dianggap tidak dapat diterima atau mengecewakan pasien dan jika harapan sama dengan pelayanan yang dirasakan, kualitanya memuaskan (Rizal, 2014).

Hasil penelitian ini didukung oleh Yuliani (2015) dengan judul Hubungan kualitas pelayanan dengan kepuasan pasien rawat inap di RSUD Dr. Sayidiman Magetan yang menyatakan bahwa ada hubungan kualitas pelayanan dengan tingkat kepuasan pasien dengan nilai $\mathrm{p}<0,005$. Artinya, bahwa semakin baik kualitas pelayanan yang diberikan pelayan kesehatan maka semakin puas pula kepuasan pasien yang menjalani pengobatan. Sudibyo (2014) didalam penelitiannya mengatakan kualitas pelayanan sangat berpengaruh pada kepuasan.

Penelitian ini juga didukung oleh Erviana (2013) yang meneliti tentang pengaruh kualitas pelayanan terhadap kepuasan pasien rawat inap, hasilnya diperoleh keterangan bahwa variabel kualitas pelayanan berpengaruh positif terhadap kepuasan pasien rawat inap. Persepsi kualitas pelayanan yang baik akan sangat berpengaruh terhadap kepuasan pasien.

Pelayanan yang berkualitas akan memberikan kepuasan kepada pasien yang menerima pelayanan tersebut. Kualitas pelayanan yang rendah dapat menyebabkan banyaknya keluhan pasien, bila hal ini tidak diatasi dengan baik maka pelayan kesehatan akan kehilangan pasien. Upaya pelayanan haruslah memberi kepuasan, tidak sematamata sembuh belaka (Sudibyo, 2014).

Kesadaran untuk menjaga kualitas perlu diupayakan guna meberikan kepuasan pada pasien. Perusahaan jasa khususnya kesehatan dituntut untuk meningkatkan kualitas pelayanan yang berorientasi pada tingkat kepuasan pasien serta mengubah pandangan negatif masyarakat terhadap pelayanan kesehatan khususnya milik pemerintah (Zaniarti, 2011).

\section{KESIMPULAN}

1. Kualitas pelayanan kesehatan yang mayoritas baik sebanyak $87,5 \%$.

2. Tingkat kepuasan pasien atas pelayanan kesehatan mayoritas kategori puas sebanyak $93,7 \%$.

3. Ada hubungan kualitas pelayanan dengan tingkat kepuasan pasien TB Paru yang menjalani pengobatan strategi DOTS di Puskesmas Helvetia Medan dengan nilai signifikasi sebesar $0,003<0,05$.

\section{UCAPAN TERIMAKASIH}

Ucapan terima kasih kami sampaikan kepada Universitas Sari Mutiara Indonesia yang telah memberikan dukungan dana dalam penelitian ini. 


\section{DAFTAR PUSTAKA}

Adiatama, T. Y. 2010. Tubekulosis Paru dan masalah penanggulangannya. UI Press, Jakarta.

Amri, P.G 2011. Kepuasan Penderita TB Paru Diwilayah Kerja Puskesmas Medan Johor. Medan: Universitas Sumatera Utara

Ardhitya, Sejati \& Sofiana.L 2014. Faktorfaktor Terjadinya Tuberkulosis : Yogyakarta

Ardhiansyah, M. 2012. Medikal Bedah. Yogyakarta : DIVA press

Arikunto, S. 2010. Prosedur penelitian : Suatu Pendekatan Praktik. (Edisi Revisi). Jakarta : Rineka Cipta

Asiah, Hamzah,. 2015. Kualitas Pelayanan Sentra DOTS Terhadap Kepuasan Pasien Di BBKPM : Makassar

Atika, Imelda. 2013. Gambaran Angka Kesembuhan Pasien Tuberkulosis Paru Di Rumah Sakit Umum Daerah Petala Bumi: Pekanbaru.

Bata, Yuristi W, dkk. 2013. Hubungan Kualitas Pelayanan Kesehatan Dengan Kepuasan Pasien Pengguna Askes Sosial Pada Pelayanan Rawat Inap Di RSUD Lakipadada Kabupaten Tana Toraja : Universitas Hasanuddin.

Budiarto, 2015. Kualitas Pelayanan Kesehatan Puskesmas Di Kecamatan Enrekang Kabupaten Enrekang: Universitas Hasanuddin.
Chitami, Widya Putri. 2013. Pengaruh Kualitas Pelayanan Dan Kepuasan Terhadap Loyalitas Pasien Rawat Jalan Dan Rawat Inap RS Otorita Batam : Universitas Widyatama.

Departemen Kesehatan Republik Indonesia. (2011). Pedoman penanggulangan nasional TBC. Jakarta: Depkes RI.

DEPKES. (2013). Riset kesehatan dasar 2013. Diakses dari http://depkes.go.id/download/riskes das2013/hasil\%20Riskesdas\%2020 13.pdf diakses pada 06 april 2016.

Dotulong, Jendra. 2015. Hubungan Faktor Resiko Umur, Jenis Kelamin dan Kepadatan Hunian dengan Kejadian TB Paru di Desa Wori.

Erviana, 2013. Pengaruh Kualitas Pelayanan Terhadap Kepuasan Pasien Rawat Inap.

Jarusliamin, Muh. 2015. Hubungan Mutu Pelayanan Kesehatan Dengan Kepuasan Pasien Uum Di Instalasi Rawat Inap RSUD Haji Kota Makassar: Universitas Hasanuddin.

Ira, Setyaningsih. 2013. Analisis Kualitas Pelayanan Rumah Sakit Terhadap Pasien Menggunakan Pendekatan Lean Servperf (Lean Service Dan Service Performance) : UIN Sunan Kalijaga

Ismaniar H., 2015. Administrasi Kesehatan Masyarakat. Dapat diakses di https://books.google.com 
Like, J.M., 2011. Analisis Faktor-faktor Yang Berhubungan Dengan Kepuasan Pasien di Poliklinik Penyakit Dalam RSUP Prof. Dr. R. D. Kandou Manado.

Made, Suadnyani Pasek \& Satyawan, Made. 2013. Hubungan Persepsi Dan Tingkat Pengetahuan Penderita TB Dengan Kepatuhan Pengobatan Di Kecamatan Buleleng.

Mahfuzhah, 2014. Karakteristik Pasien Tuberkulosis Paru di Puskesmas Tuminting: Manado.

Maidelwita, 2011. Hubungan Mutu Pelayanan Kesehatan dengan Tingkat Kepuasan Pasien Terhadap Pelayanan Kesehatan di ruangan Rawat Inap Interne RSUD Dr. M. Zein Painan.

Manurung, I.E., Hubungan Kualitas Pelayanan dengan Kepuasan Pasien di Puskesmas Pasundan: Bandung.

Nurul, Wahyuni Sri. 2013. Kepuasan Pasien TB Yang Diobati Dengan Strategi DOTS Di GHS (Government Health Service) Ponorogo.

Nurcaya, 2011. Hubungan Antara Pekerjaan, PMO, Pelayan Kesehatan, Dukungan Keluarga dengan Perilaku Berobat Pasien TB Paru.

Padila, 2013. Asuhan Keperawatan Penyakit Dalam. Yogyakarta: Nuha medika.
Pare. L.A. 2012. Hubungan Antara Pekerjaan, PMO, Pelayanan Kesehatan, Dukungan Keluarga dan Diskriminasi Dengan Perilaku Berobat Pasien TB Paru.

Praditya, Bongga. 2013. Hubungan Antara Tingkat Pengetahuan dengan Kepatuhan Penggunaan Obat Antituberkulosis Oleh Pasien Tuberkulosis Paru di Instalasi Rawat Jalan Balai Besar Kesehatan Paru Masyarakat Surakarta.

Rizal, A., Yeni, R. 2014. Hubungan Kualitas Pelayanan Kesehatan Dengan Tingkat Kepuasan Pasien di Bp. Gigi Puskesmas Kelayan Dalam: Banjarmasin.

S. Elisa. K. 2011. Hubungan Antara Umur, Jenis Kelamin, dan Kepadatan Hunian Dengan Kejadian TB Paru Pada Pasien Rawat Jalan di RSU Daerah Noongan.

Selecca, 2012. Hubungan Status Ekonomi dan Tingkat Pengetahuan TB dengan Keterlambatan Pasien dalam Diagnosis Kasus TB Paru.

Setyaningsih, 2011. Mutu Pelayanan dan Tingkat Kepuasan Pasien di Klinik Terpadu Politeknik Kesehatan Surakarta.

Sianturi Ruslantri, 2014. Analisis Faktor Yang Berhubungan Dengan Kekambuhan TB Paru: Semarang.

Ulfa, 2015. Hubungan Kualitas Pelayanan Rawat Inap Dengan Tingkat 
Kepuasan Pasien di Bangsal Mawar I: Surakarta.

Yuliani, 2015. Hubungan Kualitas Pelayanan dengan Kepuasan Pasien Rawat Inap di RSUD Dr. Sayidiman Magetan.

Zaniarti, 2011. Hubungan Kualitas Pelayanan Kesehatan dengan Kepuasan Pasien Rawat Inap Jamkesmas di RSUD Salatiga. 